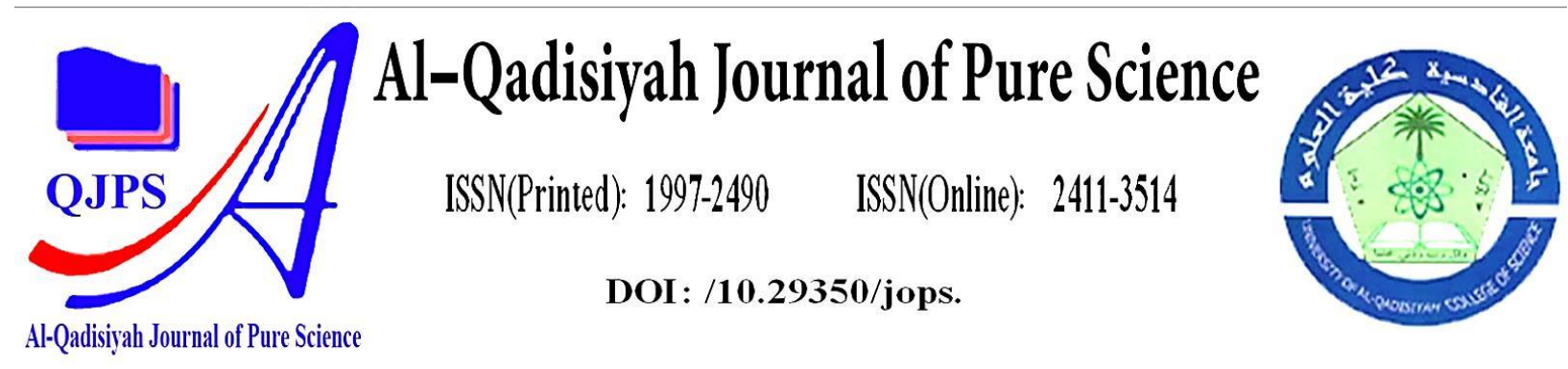

\title{
Using GIS and Remote Sensing Satellite Data to mapping and monitoring Shatt Al-Arab Estuary and nearby coastline Southern Iraq
}

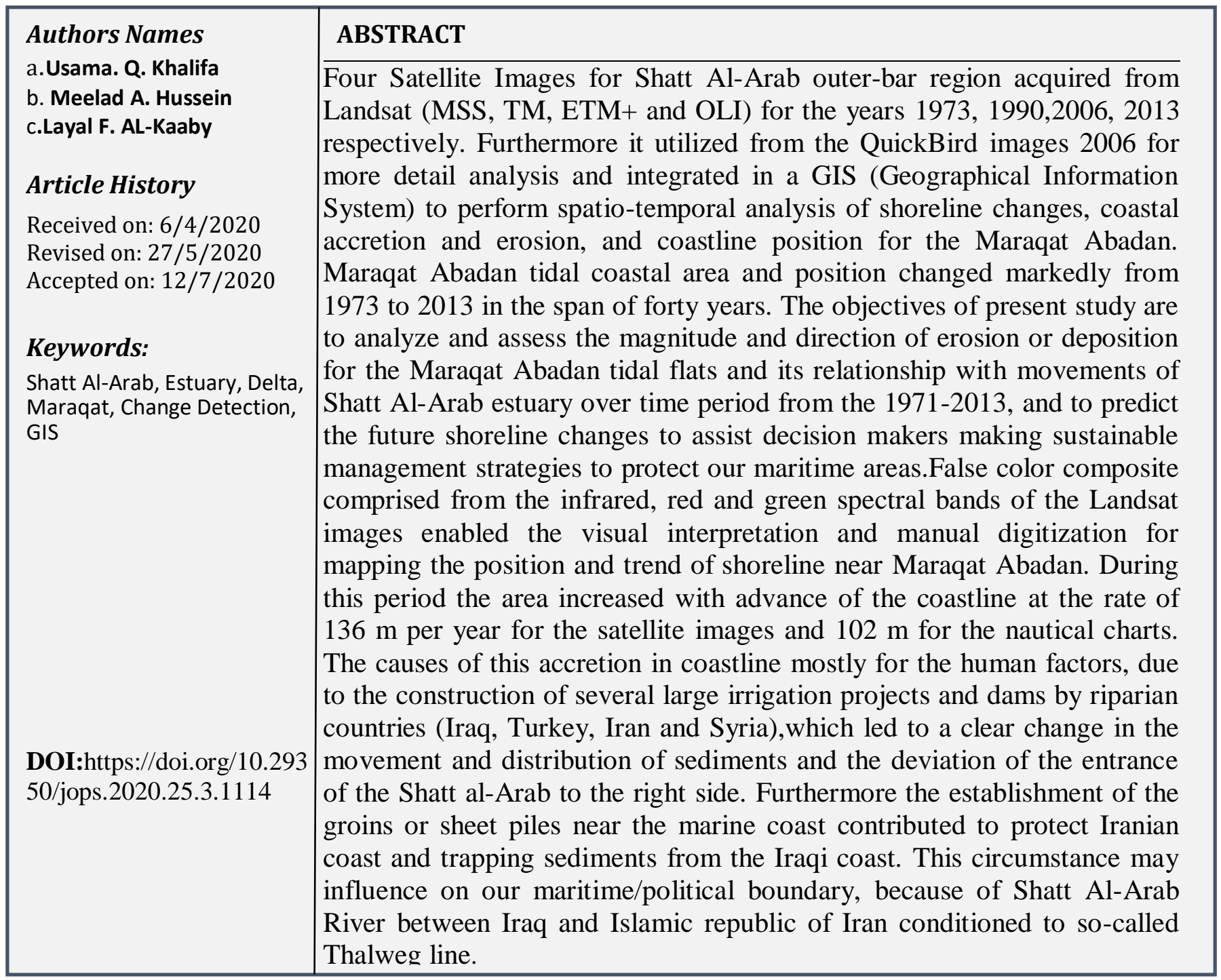

a-Marine Science College University of Basrah,alwhaely72@gmail.com b- Marine Science College University of Basra, meelad.79@gmail.com

C-College of Oil and Gas Engineering Basrah University for Oil \& Gas, lfsgeo@yahoo.com 


\section{Introduction}

A Coastline/Shoreline defined as the boundary when the sea surface contact the land body. [14, 32]. Among linear features in the earth's surface, the coastline area displaying a dynamic nature [33 in 61].The coastal areas are always physically and ecologically being change. It changed due to natural and human factors. The primary natural factors are comprise (waves, currents, tides and winds), as well as other factors such sand sources and sinks, changes in relative sea level, geomorphological characteristics of the coast. The human anthropogenic factors that changed coast are construction of artificial structures, mining of beach sand, offshore dredging or building of dams or rivers [51]. Consequently monitoring of coastline changes benefits to appreciate the coastal responses to these factors. Shoreline position is one of the primary geo-indicators for monitoring coastal changes as the shoreline is sensitive to natural processes (e.g., regional tectonic processes, fluvial processes, water quality, sea level and sediment supply) and anthropogenic alteration (e.g., construction of coastal structures, construction of river dams, and mining of coastal materials) [47].

A long term natural advance of shoreline position inferred a decrease in wave energy, an increase in sediment supply, or a low relative sea level. On the contrary, a natural retreat of shoreline position indicates an increase in wave energy, a decrease in sediment supply, a rise in sea level, or a combination of those causes [47].

The Coastline mapping and change detection are important for safe navigation, resource management, environmental protection, and sustainable coastal development and planning [24]. Following the coastline change is more than to investigate the potential relationship between the spatial-temporal patterns of sea-level rise and those of coastline changes, it is possible to provide essential information for government administrators and coastal managers to make scientific and rational policies for land use planning and sustainable development of coastal zones [50,56]. Remote sensing and geographical information system (GIS) techniques have been using widely to evaluate changes incoastal shorelines $[16,31,8,13,53,48,40,57,20,35,2018 ; 39,27]$. These utilized from thecapability of repeatedsynoptic viewingof satellite data and the various options in multispectral bands and high resolution data [25]as well as the numerous services provided by geographic information system i.e. (analysis, stores, manipulation and visualization) for monitoring and mapping coastal/shore areas, than datacollected by conventional techniques[28]. The optical imaging sensors are essential technology in coastal mapping through their 
availability and easy to interpretation. Moreover,absorption of infrared wavelength area by water and its strong reflection by vegetation and soil make such images best combination for mapping the spatial distribution of land and water. These characteristics of water, vegetation and soil make the use of the images that include visible and infrared bands mostly used for coastline mapping [23 in 8].

Some of studies considered the tidal height as a proxy to evaluate coastal change detection, and therefore, the accuracy of shoreline position resulting from a satellite images based on the range of tidal height at the satellite flyover time [62]. Otherwise, there is attempt to use satellite images obtained matching tidal height and under clear atmospheric condition [64]. For the tidal-induced water level fluctuation, there are studies conducted for reduced such impact. [17, 64, 49, 63]. The image processing techniques differs according the nature of the coast, accuracy and scale required, and availability of the imagery series data and software and program as well as image processing techniques(Table.1).

There are several studies for change detection of coastal areas that connected satellite images with high water level $[64,54,42,43,51,18,2013 ; 21]$. The primary and vital step in the shoreline change detection is the selection of suitable feature that can be considered as shoreline proxy or indicator that can represent the current position and can be as reference for monitoring the change in different periods. $[14,46]$. These proxy shorelines are consist of two types: a visible and distinguishable line in coastal imagery known as High Water Line (HWL) or intersection of a tidal datum with coastal profile (such MHW, MLW, etc.) [14].

Among all the vertical levels that are used in the shoreline change detection, HWL is very common as it is easily interpretable in photos [14]. After determination, shoreline can be extracted by manual digitization or some automated techniques in GIS [43,3]. Furthermore, the shoreline movement, erosion and accretion rates can be calculated and its future trends can be predicted $[19,52]$.

The objectives of present study are toanalyze and assess the magnitude and direction of erosion or deposition for the Maraqat Abadan tidal flats and its relationship with movements of Shatt AlArab estuary over time period from the 1971-2013, and to predict the future shoreline changes to assist decision makers making sustainable management strategies to protect our maritime areas. This study highlightsthe coastal monitoring and analyzing the shoreline change using remote 
sensing and GIS techniques with the confirmationof using satellite images acquired at same tidal height for improving mapping efficiency and accuracy.

Table 1. Shoreline Change Detection Studies throughout the World

\begin{tabular}{|c|c|c|c|c|c|c|}
\hline References & $\begin{array}{l}\text { Source of Tidal height } \\
\text { (Software, Model, } \\
\text { Website, historical Tide } \\
\text { gauge) }\end{array}$ & $\begin{array}{l}\text { Satellite } \\
\text { Images } \\
\text { Time } \\
\text { series }\end{array}$ & $\begin{array}{l}\text { Shoreline } \\
\text { Extract }\end{array}$ & $\begin{array}{l}\text { Study } \\
\text { Area }\end{array}$ & $\begin{array}{l}\text { Tidal } \\
\text { range }\end{array}$ & $\begin{array}{l}\text { Change } \\
\text { Factors } \\
\text { Induced }\end{array}$ \\
\hline [64] & $\begin{array}{l}\text { https://tidesandcurrents.no } \\
\underline{\text { aa.gov/ }}\end{array}$ & $\begin{array}{l}\text { TM- } \\
\text { ETM+ }\end{array}$ & $\begin{array}{l}\text { - Edge filter } \\
\text { algorithm- } \\
\text { - Tasselled cap } \\
\text {-Unsupervised } \\
\text { classification } \\
\end{array}$ & $\begin{array}{l}\text { west- } \\
\text { centralFlo } \\
\text { rida coast }\end{array}$ & $\begin{array}{l}\text { High } \\
\text { tide }\end{array}$ & Hurrican \\
\hline [41] & $\begin{array}{l}\text { South China Branch of } \\
\text { State } \\
\text { Administration } \\
\text { (Neilingding) }\end{array}$ & $\begin{array}{l}\text { MSS-TM- } \\
\text { ETM+- } \\
\text { SPOT }\end{array}$ & $\begin{array}{l}\text { - Classification } \\
\text { - Slicing } \\
\text { - Digitizing }\end{array}$ & $\begin{array}{l}\text { Pearl } \\
\text { River } \\
\text { Estuary, } \\
\text { China }\end{array}$ & $\begin{array}{l}\text { Low } \\
\text { tide }\end{array}$ & $\begin{array}{l}\text { Sediment } \\
\text { ation and } \\
\text { Man- } \\
\text { made } \\
\text { structures }\end{array}$ \\
\hline [49] & $\begin{array}{l}\text { Tide } \\
\text { Model Driver and the } \\
\text { Oregon State University } \\
\text { Tidal Inversion Software }\end{array}$ & $\begin{array}{l}\text { TM } \\
\text { ETM+ }\end{array}$ & - NDWI & $\begin{array}{l}\text { Tidal Flat } \\
\text { China }\end{array}$ & $\begin{array}{l}\text { High } \\
\text { tide } \\
\text { Low } \\
\text { tide }\end{array}$ & $\begin{array}{l}\text { sea level } \\
\text { rise }\end{array}$ \\
\hline [40] & $\begin{array}{lcr}\text { Institute } & \text { of } & \text { Marine } \\
\text { Geology } & \text { and } & \text { Geophysis } \\
\text { (IMGG) on } & \text { Hondau } \\
\text { Station } & & \end{array}$ & $\begin{array}{l}\text { MSS-TM- } \\
\text { ETM+ } \\
\text { ALOS } \\
1975-2009\end{array}$ & $\begin{array}{l}-\quad \text { Band } \\
\text { rationing } \\
-\quad \text { Threshold } \\
\text { technique }\end{array}$ & $\begin{array}{l}\text { Estuary } \\
\text { area of } \\
\text { the Red } \\
\text { river } \\
\text { system, } \\
\text { Vietnam } \\
\end{array}$ & $\begin{array}{l}\text { High } \\
\text { tide } \\
\text { Low } \\
\text { tide }\end{array}$ & $\begin{array}{l}\text { Sedimentat } \\
\text { ion and } \\
\text { Erosion by } \\
\text { Red River } \\
\text { andThai } \\
\text { Binh } \\
\end{array}$ \\
\hline$[51]$ & Tamil Nadu Port & $\begin{array}{l}\text { MSS, TM, } \\
\text { ETM+ and } \\
\text { OLI } \\
1978-2014 \\
\end{array}$ & $\begin{array}{l}\text { - Layer } \\
\text { Stacking, } \\
\text { - digitization } \\
\text { USGS DSAS } \\
\text { End Point Rate }\end{array}$ & $\begin{array}{l}\text { Tamil } \\
\text { Nadu, } \\
\text { India Bay } \\
\text { of Bengal }\end{array}$ & $\begin{array}{l}\text { High } \\
\text { Tide }\end{array}$ & $\begin{array}{l}\text { Wave } \\
\text { action }\end{array}$ \\
\hline [63] & $\begin{array}{l}\text { https://www.co- } \\
\text { ops.nos.noaa.gov/ } \\
\text { GPS Surveying } \\
\text { Rockport station }\end{array}$ & $\begin{array}{l}\text { TM- } \\
\text { ETM+ } \\
\text { OLI } \\
\text { LIDAR }\end{array}$ & $\begin{array}{l}\text { - Thresholding } \\
\text { of MNDWI } \\
\text {-Water } \\
\text { frequency index } \\
\text { (WFI) } \\
\end{array}$ & $\begin{array}{l}\text { Texas } \\
\text { Coastal } \\
\text { Area } \\
\text { Intertidal } \\
\text { area }\end{array}$ & $\begin{array}{l}\text { High } \\
\text { tide } \\
\text { Low } \\
\text { tide }\end{array}$ & $\begin{array}{l}\text { Hurricane } \\
\text { Sea Level } \\
\text { Variation }\end{array}$ \\
\hline
\end{tabular}




\section{Study Area}

\section{1- Location and Geographical Description}

Geographically, Shatt Al-Arab Estuary located at the northwestern part of the Arabian/ Persian Gulf. The study are lies between $30^{\circ} 5^{\prime} 0^{\prime \prime}-29^{\circ} 50^{\prime} 10^{\prime \prime}$ North latitude and $48^{\circ} 30^{\prime} 00^{\prime \prime}-48^{\circ} 50^{\prime} 00^{\prime \prime}$ East longitude. The area bounded to the west by Khor Abdallah, and the east by the estuary of Bahmshiras shown in (Figure 1).Tectonically, the area located on the unstable shelf, particularly in the Mesopotamian zone, Zubair Subzone [15,9]

Shatt Al-Arb River originated from the confluence Tigris and Euphrates Rivers at Qurnah City $70 \mathrm{Km}$ north of Basrah Governorate. Downstream of Qurnah, Shatt Al-Arab River flowssouthwestern for $204 \mathrm{Km}$ shared between Iran and Iraq before drain in Arabian/Persian Gulf formed Delta. Besides to the Euphrates and Tigris Rivers, the Karkheh and the Karun subbasins contribute water to the Shatt al Arab. Both the Karkheh and the Karun Rivers originate in the central zone of the Zagros Mountains in Iran and discharge into the Shatt al Arab [26]

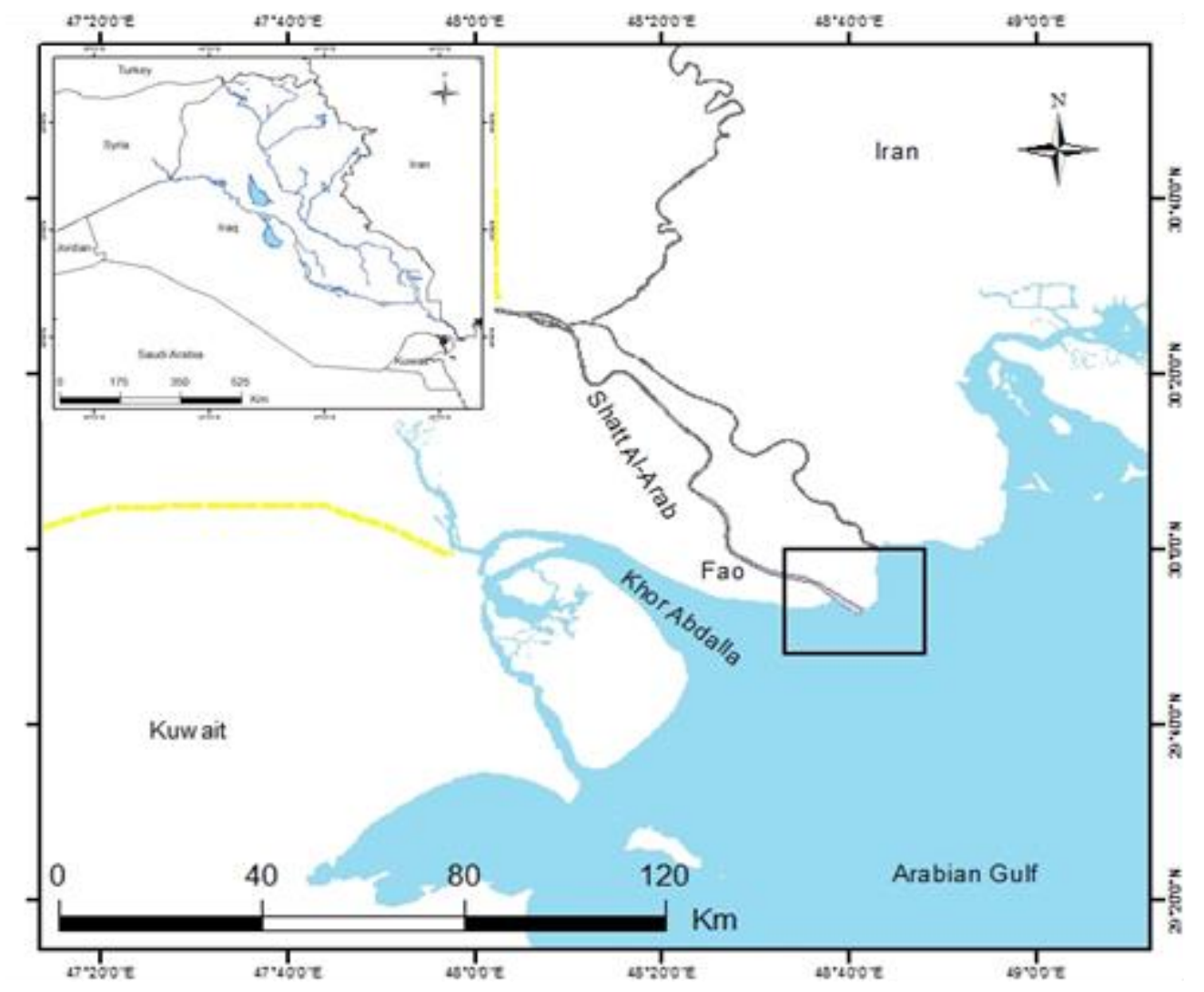

Figure 1. Location of study area 


\section{2- Hydrologic Setting}

In order to understand the natural hydrologic system of Shat Al-Arab River, researchers have investigated the hydrological system of Shatt Al-Arab from its (Discharge and catchment characteristics) and the tidal effect, and Sediment budget. All this characteristics have been differed started from the past quarter $20^{\text {th }}$ century.

Generally the hydrological regime of Shatt Al-Arab depends on the hydrology of the (Tigris, Euphrates, and Karun) also to water of Arabian Gulf. In other words the rate of water level changes in Shatt Al-Arab drainage basin, firstly is influenced by the river regime, and secondly the daily alteration of the water by the tide in the Gulf. It is important to consider these variables as distinctive character of the fluvial level system of Shatt Al-Arab.

There are number of important tributaries considered as the source of water and sediments of Shatt Al-Arab River. These tributaries are represented by the rivers (Tigris, Euphrates, and Karun). In addition to marshes regions that border Shatt Al-Arab from the upper section, which are represented by Hammar Lake that drains its water at Qurmat Ali into the east of Shatt alArab. Presently this tributary is considered as a branch [45]. As well as, Al-Huwaiza Marsh that flow via Al-Swaib waterway that discharge its water into Shatt Al-Arab River (5 km south of Qurna city) [4].

The hydrological studies point out that the water discharge of Shatt Al-Arab decreased dramatically than it was in the past quarter 20th century, when it reach to $1500 \mathrm{~m}^{3}$ (Hussein et al, 1991) and continued to decline to $\left(724-815 \mathrm{~m}^{3}\right)$ in the late nineties of the last century [11], reach after the 21 st century to low value between $50-70 \mathrm{~m}^{3}[5,2]$. The present situation of the river hydrological system is completely different. Since 2010, Shatt Al-Arab River depends mainly on the freshwater flow from the Tigris River [5].Nowadays, Shatt Al-Arab water supply decreased, because of construction of large-scale hydropower and reservoirs dams and most important water diversions in the upstream basins in Turkey, Syria, Iran and Iraq.

The variation of water level inthisprocess is about $2 \mathrm{~m}$ between two sequential tides [36]. As well as, Shatt Al-Arab is affected by the tidal phenomena. It is mixedtype ranging from (diurnal to semi-diurnal) but the semi- diurnal is thedominant type which it characterized by unequal range as well as time, i.e.occurrence of two tides and two ebbs in one day [12].The Tidal range varies along Shatt Al-Arab course. It reaches $3 \mathrm{~m}$ at Fao city and $1 \mathrm{~m}$ at Al-Ma`aqal, while it decreases away towardsQurna [1]. Thus, according to Davies`s [22 in 30] classification 1980 of tide ranges 
[30] the region may be considered as a microtidal in type, which variesbetween 2-0 $\mathrm{m}$, [1]. The maximum difference between high and low water levels may approach $1.7 \mathrm{~m}$ in summer and $1.5 \mathrm{~m}$ in winter [6]. Velocity of tide and ebb currents in Shatt Al-Arab estuary ismoderate to high. However, the tidal currents take a period of about 40minute in spring tide state after occurrence of upper level of Shatt Al-Arabwater, whereas in neap tide state where the water is in lower level, it takesperiod of about one hour after occurrence of upper level too. On the otherhand the ebb currents take period of 30 minute after occurrence of lowerlevel of Shatt Al-Arab water in spring tide state, whereas in neap tide stateit takes a period of one hour after occurrence of lower level too [44].

The total annually dissolved load that Shatt Al-Arab drains to theGulf is about 30 million ton. The annual suspended load of Shatt Al-Arabnorth to the confluence with Karun River is about 22 million ton [1]. Whereas it is about 20 million ton downstream the confluence and9.5 million ton at Fao [11]. The bed load is too low to beconsidered in Shatt Al-Arab, it is between 85 thousands ton/year [11].Shatt Al-Arab formed delta described as tide dominated affected slightly with waves[7] according to Gallawy's classification 1975 [29].The sediment of the Shatt al-Arab in the (Delta)mainly consists of $60 \%$ silt, $25 \%$ clay and $15 \%$ sand. The remarkable feature is deposited in main course of Shatt Al-Arab near Out Bar region was characterized by the longitudinal sediment bars. The Coriolis phenomena occurred in Shatt Al-Arab estuary thereforeit caused transportation and redistribution of the sediment load besidesits erosion effects on the Iraqi's coast [7]. The water circulation in the Arabian Gulf seems to be counter clockwise, passing northwesterly along the Iranian coast and recession water southeasterly along the Arabian coast (Emery, 1956).

Sea level has increased globally in recent decades as a result of global warming that impact consequently on the increased temperature and droughts that related primarily to the greenhouse effect because increasing concentrations of carbon dioxide, methane and nitrous oxide generated by human activities [37]. As estimated by Alothman et al. (2014) the relative of sea level for northern Arabian/Persian gulf included the outlet of Shatt Al-Arab recorded about $2.2 \pm 0.5$ mm/year over the period 1979-2007. 


\section{Material and Method}

\section{1- Data Source}

In this study, Landsat MSS (Multispectral Scanner), TM (Thematic Mapper), ETM+ (Enhanced Thematic Mapper Plus) and OLI (Operational Land Imager) datasets acquired from (USGS) website [60] for 1973 to 2013 were used to demarcate the shoreline changes along Maraqat Abadan. Table 2 indicates the data sources used for the coastlinechange detection. The datasets were obtained predominantly from June to July in order to acquire cloud free images, as well as, the highest tide in spring occurred predominately in summer season [10]. Itwere acquired in the same tidal height with $3 \mathrm{~m}$ near the station tide (Shatt A-Arab Out Bar). The tide level obtained using the admiraltytotal tide software (ver.1) [58] (Figure. 2), with cross checking website Sailwx (https://www.sailwx.info/tides/tidemap.phtml). High resolution data of Quick-Bird satellite with the spatial resolution $0.6 \mathrm{~m}$ (Table.2). Multi-date admiralty charts available in Marine Science Center Remote Sensing Lab.for the time periods (1971, 1986, 2004, 2008) (Table 3).

\section{2- Image Processing}

As the satellite images have been processed to level L1 T level. So the geometric rectifications are not required. All image data were projected to WGS84 datum UTM Zone 39N. The atmospheric correction is not applied as the vegetation and any other indices are not conducted in present study. The Landsat satellite images obtained were taken as an input for spectral preprocessing. Using layer stacking method, the individual bands of the satellite data were converted into a False Color Composite image using ERDAS Imagine ver.14 for displaying best contrast between land-water boundary in the satellite image and thus shoreline position was identified and demarcated.

\section{3- Shoreline Extraction}

The shoreline vectors have been created using ArcGIS ver. 10.1 (Arc-Map Interface) for two source of data used in study (Satellite Images and Admiralty Charts). These vector layers created as (Point, Polyline and Polygon). For satellite images high water line boundary was regarded as the shoreline proxy and demarcated using visual interpretation andscreen digitization method. As concerned the admiralty charts, it was scanned and converted to tiff file format then added to Arc-Map for georeferencing. It once georeferenced to the same coordinate system WGS 84- 
UTM Zone 39N. Then, it created shapefiles polygons for the zero-line areas that reflect the low water tide and demarcated these areas using manual screen digitization. The UTM coordinates ( $\mathrm{x}$ and $\mathrm{y}$ ) for each end points in shoreline were used to calculate $\mathrm{m}$ EPR for both $\mathrm{x}$ and $\mathrm{y}$ locations of each point.

The position of these shapefiles calculated to find the accretion rate that caused the change in coastline of Abadan tidal flats. Average shift in meters was calculated and using duration ofoccurrence of change over the span time and for all time of data used in study using the formula: Rate of accretion meter/ year= distance $\mathrm{f}$ shifts/ total time period (span) (Figure-3).

Table 2. Specifications of the spatial data used in the study

\begin{tabular}{|l|l|l|l|l|l|l|}
\hline $\begin{array}{l}\text { Satellite } \\
\text { Name }\end{array}$ & $\begin{array}{l}\text { Sensor } \\
\text { Type }\end{array}$ & $\begin{array}{l}\text { Path } \\
\text { Row }\end{array}$ & $\begin{array}{l}\text { Date } \\
\text { Acquisition }\end{array}$ & $\begin{array}{l}\text { Spatial } \\
\text { Resolutio } \\
\mathbf{n}(\mathbf{m})\end{array}$ & $\begin{array}{l}\text { Local } \\
\text { Time }\end{array}$ & $\begin{array}{l}\text { Tidal } \\
\text { height (m) }\end{array}$ \\
\hline LANDSAT 1 & MSS & $177 \_39$ & $\begin{array}{l}1973-07-26 \\
6: 45: 24 \text { AM }\end{array}$ & 60 & $6: 45: 24$ AM & $3 \mathrm{~m}$ \\
\hline LANDSAT 5 & TM & $165 \_39$ & $\begin{array}{l}1990-06-20 \\
6: 36: 02 ~ A M\end{array}$ & 30 & $6: 36: 02$ AM & $3 \mathrm{~m}$ \\
\hline LANDSAT 7 & ETM+ & $165 \_39$ & $\begin{array}{l}2006-07-10 \\
7: 33: 08 ~ A M\end{array}$ & 30 & $7: 33: 08$ AM & $3 \mathrm{~m}$ \\
\hline LANDSAT 8 & OLI & $165 \_39$ & $\begin{array}{l}2013-07-21 \\
7: 17: 40 ~ A M\end{array}$ & 30 & $7: 17: 40$ AM & $3 \mathrm{~m}$ \\
\hline $\begin{array}{l}\text { Digital } \\
\text { Globe }\end{array}$ & Quick-Bird & 29N_48E & $2006-05-07$ & 0.6 & Unknown & Low tide \\
\hline
\end{tabular}

Table 3. List of Admiralty chart used in study

\begin{tabular}{|l|l|l|}
\hline Name of Charts & ID & Year of Charts \\
\hline $\begin{array}{l}\text { Khawr Abd Allah and Approaches to Shatt } \\
\text { Al-Arab }\end{array}$ & 1235 & 2008 \\
\hline $\begin{array}{l}\text { KhorAbdallah and Approaches to Shatt Al- } \\
\text { Arab }\end{array}$ & 1235 & 2004 \\
\hline Kuwait 1 & Kuwait 1 & 1986 \\
\hline Entrance to Shatt Al-Arab & 3842 & 1971 \\
\hline
\end{tabular}

\section{Result and discussion}

Satellite data and nautical admiralty maps for 40 years were compared quantitatively to delineate shoreline positions in both tide level (High, Low). Depositional/ progradingshoreline are observed at the Abadan tidal flats.(Table 4) summaries rates of the Maraqat Abadan tidal flats 
changes as average of the erosion and accretion values on generated transects for the two sets of data Satellite images and nautical charts. The end point rate values represents the movement of the Abadan tidal flats toward the gulf (accretion rate). The position of Maraqat Abadan started moving forward toward the gulf from year 1973with distance 2416 m from year 1973 to 1990 with the advance rate about $142 \mathrm{~m}_{\text {per }} \mathrm{yr}^{-1}$ for 17 time span(Figure. 3). The sediment supply near the mouth of Shatt Al-Arab that drained in Delta and estuary may indicate growth of the Abadan shoreline in this period. The discharge of Shatt Al-Arab River with its tributary Karun was in high level as mentioned by the hydrological studies[36].Since the last 1980s and beginning of 1990 past century, Shatt Al-Arabsediment supplyreached 22 million ton of suspended load [1].

Over the period of 1990 to 2006 for 16 years the advance rate of Abadan tidal flats constantly increased but with low rate was $139 \mathrm{~m} \mathrm{yr}^{-1}$ (Figure. 3). The Shatt Al-Arab river discharge decreasesintensely where the discharges became $\left(724 \mathrm{~m} 3-815 \mathrm{~m}^{3}\right)$. Thus because the construction of irrigation water storage dams and flood control projects in the riparian countries (Turkey, Syria Iraq and Iran) of the Mesopotamian rivers basin (Altinbilek, 2004; 38]. Accordingly the sediment supply drained in Shatt Al-Arab mouth declines which it evaluated to 9.5 million ton [11].

Table 4. End point rate for Abadan Maraqat from satellite images time series

\begin{tabular}{|l|c|c|c|}
\hline $\begin{array}{c}\text { Date of Satellite } \\
\text { imagery }\end{array}$ & Time Spans yrs. & Rate $\left(\mathrm{m} . \mathrm{year}^{-1}\right)$ & $\begin{array}{c}\text { End Point Position } \\
\text { (Distance, } \mathrm{m})\end{array}$ \\
\hline $1973-1990$ & 17 & 142 & 2416 \\
\hline $1990-2006$ & 16 & 139 & 2234 \\
\hline $2006-2013$ & 7 & 115 & 810 \\
\hline Total & 40 & & 5460 \\
\hline Rate $\left({\left.\mathrm{m} . \text { year }^{-1}\right)}^{\mid}\right.$ & 136.5 & 136.5 \\
\hline
\end{tabular}

Despite the deposition process is noticed along the Iranian shoreline (Abadan Maraqat), Iran government establishedsea protection structures like groynes or sheet piles etc. causes trapping sediments along the protection structures thus reduces the sediment supply to the Iraqis' shoreline. The high resolution satellite image Quick-Bird 2006 showed set of sheet pile to protect the coastline from the erosion processes and for trapping sediments purposes(Figure.4).

The period of the 2006 to 2013 for 7 years the rate of shoreline advance gradually decreased southwest from the Shatt Al-Arab mouth compared with past times pans. The rate of end point reaches $115 \mathrm{~m} \mathrm{yr}^{-1}$ over a distance $(810 \mathrm{~m})$. Recently the discharge and accordingly sediment supply were in the lowest level. In 2008 the Iranian government forwarded Karun River to the 
Bahmshirwaterway, which helped recover the vegetation and agricultural fields in this area [34]. Also the Euphrates River cut-off its water and diverted to Marshes. So the freshwater flow of Shatt Al-Arab depends mostly on Tigris River[5].All the distance for the whole time series reached about $5 \mathrm{Km}$ and rate of movement with $\left(136.5 \mathrm{~m} \cdot \mathrm{yr}^{-1}\right)$. This impact to deflection of the entrance of Shatt Al-Arab estuary for the right direction.The right direction of the Abadan shoreline may attributed to effect of water circulation occurred in the northern part of Arabian/Persian Gulf, as mentioned in studies (Emery, 1956; 7, 10].

The historical nautical charts for years (1971, 1986, 2004 and 2008) representthe Lowest Astronomical Tide (LAT)showed changes through their areas and positions(Table. 5). The intertidal zone for Maraqat Abadan showed variation in its area and direction in the period from1971 to 2010. (Figure. 5).

Table 5 Area of the intertidal zones fromNautical Admiralty Charts used in study

\begin{tabular}{|l|c|c|c|c|}
\hline Name of Charts & Chart ID & Chart Date & Area Km2 & $\begin{array}{c}\text { Rate of } \\
\text { Advance }\end{array}$ \\
\hline Entrance to Shatt Al-Arab & 3842 & 1971 & 46.37 & 0 \\
\hline Kuwait 1 Kuwait 1 & 1986 & 132.81 & 0.58 \\
\hline $\begin{array}{l}\text { Khor Abdallah and } \\
\text { Approaches to Shatt Al-Arab }\end{array}$ & 1235 & 2004 & 82.57 & 3.03 \\
\hline $\begin{array}{l}\text { Khawr Abd Allah and } \\
\text { Approaches to Shatt Al-Arab }\end{array}$ & 1235 & 2008 & 83.38 & 3.8 \\
\hline Average & & $37 \mathrm{yr}$ & & $102.7 \mathrm{~m} \mathrm{yr}^{-1}$ \\
\hline
\end{tabular}

The total distance of Maraqat Abadan advanced progressively about $3.8 \mathrm{~km}$ i.e.(2 nautical mile).It is noteworthy, the Iraqi territorial sea extends to distance not exceeding 12 nautical milesmeasured from baselines that represents lowest water level as referenced in United Nations Convention on the Law of the Sea(UNCLOS)[59]. While the rate of intertidal advance about $\left(102.7 \mathrm{~m} \mathrm{yr}^{-1}\right)$.The advance of shoreline position may be attributed toa decrease in wave energy, an increase in sediment supply, or a low relative sea level or combination those causes[47].On the other hand, the shifts of the position baseline may generate some critical consequences related to maritime boundary between the neighboringcountries. Since the baseline subjected to change spatially and temporarily which require redraw and calculate the new baseline which effect maritime boundaries[55]. 


\section{Conclusion}

It has been found that the coastline of Abadan is very dynamic accumulative coastal environment. It is a changeable region facing several natural and anthropogenic factors that increase the deposition process, for the last four decades. The coastline in this area showed advancing in position and direction in different water level (high, low) tide, using historical time series Landsat data and Nautical chartsintegrated in a geographic information system (GIS). Both natural and anthropogenic factors contributed for increasing the extent of the Abadan coastal area. This situation may influence on our maritime/political boundary or territorial waters. The study demonstrates the applicability and usefulness of historical Landsat data for change detection studies of the coastal environment with conformation that the satellite images should be at same tidal height for the accuracy change detection outputs.

\section{Future Work}

With the beginning of the $21^{\text {th }}$ century, different types of the remote sensors, platforms and techniques are available. As far as the sensor type is concerned, Synthetic Aperture Radar (SAR) sensors (ALOS, Sentinel-1), characterized by the socalled "all-weather" and "all-day" working capabilities. These techniques are became effective tool for mapping the coastal area. Through their polarimetry and interferometry characteristics can provide more detail about the surface and subsurface (underwater topography) of coastal zones. So, a further study for change detection of the present study area based on new generation of SAR data can be conducted.

\section{References}

[1] Abdullah, S. S., 1990. An investigation to river load of Shatt Al-Arab in Basrah. Unpublished M.Sc. Thesis, Marine Science Center, Univ., of Basrah, 98p, [In Arabic].

[2] Abdullah, S.S., Lafta, A. A., Al-Taei, S. A. and Al-Kaabi, A. H., 2016. Flushing Time of Shatt AlArab River, South of Iraq. Mesopot. J. Mar. Sci., 2016, 31(1): pp.61-74.

[3] Aedla, R., Dwarakish, G. S. and Reddy, D. V. 2015. Automatic Shoreline Detection and Change Detection Analysis of Netravati-Gurpur River mouth Using Histogram Equalization and Adaptive Thresholding Techniques. Aquatic Procedia, 4, pp. 563-570. https://doi.org/10.1016/j.aqpro.2015.02.073. 
[4] Al-Asadi, S., 2013. Hydrological characteristics for Al-Sweib River and environmental importance, The Arab Gulf, vol.41, No., 1-2, pp.157-181.

[5] Al-Asadi, S., Al-Mahmood, H. K. and Abdallah, S. S., 2015. Estimating the minimum amount of the net discharge in Shatt Al- Arab River (South of Iraq). Adab Al-Basrah, no.72 [In Arabic]

[6] Al-Badran, A., A., 1987. Factors influencing river bank stability in the Tigris and Euphrates and Shatt AL-Arab water ways, Iraq. Unpublished Ph.D. Thesis, Univ., of Dundee, 377p.

[7] Al-Badran, B., N., 2004. Delta of River Shatt Al-Arab, south Iraq sedimentological study. Marina Mesopotamica, Vol. 19, No., 2, pp: 311-322.

[8] Alesheikh, A. A., Ghorbanali, A., and Nouri, N., 2007. Coastline change detection using remote sensing. International Journal of Environmental Science and Technology. https://doi.org/10.1007/BF03325962.

[9] Al-Khadhimi, J. A. M., Sissakian, V. K., Fattah, A. S., and Dikran, D. B., 1996. Tectonic Map of Iraq. Baghdad.

[10] Al-Mahdi, A.A., Abdullah, S.S. and Husain, N.A., 2009. Some Features of the Physical Oceanography in Iraqi Marine Waters. Mesopotamian Journal of Marine Science, Vol. 24 No. (1) pp: 13 -24 .

[11] Al-Mansoury, F. Y., 1996. Sediment transport in the lower reach of Shatt Al-Arab. Unpublished M.Sc. Thesis, College of Agriculture, Univ., of Basrah, 119p, [In Arabic].

[12] Al-Ramadan, B. M. and Pastour, M., 1987. Tidal characteristics of Shatt Al-Arab River. Marina Mesopotamica, Vol., 2, No.1, pp: 15-28.

[13] Bedini, E., 2007. Use of GIS and Remote Sensing to detect change along the coastline segment between Shkumbini and Semani rivers, central Albania. Bulletin of the Geological Society of Greece, 40 (4), 1916. https://doi.org/10.12681/bgsg.17218

[14] Boak, E. H. and Turner, I. L., 2005. Shoreline Definition and Detection: A Review. Journal of Coastal Research, 4 (21), 688-703. https://doi.org/10.2112/03-0071.1

[15] Buday, T. and Jassim S. Z., 1987. The Regional geology of Iraq, Vol.2, Tectonism Magmatism and Metamorphism. Edited by I. I. Kassab and M. J. Abbas. Baghdad.

[16] Chen, L. C., and Rau, J. Y., 1998. Detection of shoreline changes for tideland areas using multitemporal satellite images. International Journal of Remote Sensing, 19(17), 3383-3397. https://doi.org/10.1080/014311698214055

[17] Chen, W. W. and Chang, H. K., 2009. Estimation of shoreline position and change from satellite images considering tidal variation. Estuarine, Coastal and Shelf Science, 84(1), 54-60. https://doi.org/10.1016/j.ecss.2009.06.002 
[18] Choudharay R., Gowthaman, R. and Kumar, V. S., 2013. Shoreline change detection from Karwar to Gokarna - South West coast of India using remotely Sensed data. International Journal of Earth Sciences and Engineering, Vol. 6, No., 3, pp. 489-494. http://drs.nio.org/drs/handle/2264/4386

[19] Dar, I. A., and Dar, M. A., 2009. Prediction of shoreline recession using geospatial technology: a case study of Chennai Coast, Tamil Nadu, India. Journal of Coastal Research, pp.1276-1286.

[20] Darwish, K., Smith, S. E., Torab, M., Monsef, H., and Hussein, O., 2017. Geomorphological Changes along the Nile Delta Coastline between 1945 and 2015 Detected Using Satellite Remote Sensing and GIS. Journal of Coastal Research, 33(4), 786-794. https://doi.org/10.2112/jcoastres-d-16-00056.1

[21] Das, A., 2013. Integrated Land-Use Study and Shoreline Changes along Shankarpur -Mandarmoni Coast line, West Bengal Using Remote Sensing and GIS Technique. Indian Cartographer, vol. 33, p. 6.

[22] Davies, J.L., 1980. Geographical Variation in Coastal Development. Longman, London, p. 204. In

[23] DeWitt, H., Weiwen, F., and Feng, J. R.,2002. Semi-Automated construction of the Louisiana coastline digital land-water Boundary using Landsat TM imagery, Louisiana's Oil Spill Research and Development Program, Louisiana State University, Baton Rouge, LA 70803.In [8]

[24] Di, K., Ma, R., Wang, J., Li, R., 2004. Coastal mapping and change diction using high resolution IKONOS satellite imagery. http://shoreline.eng.ohio state.edu/research/diggov/DigiGov.html.

[25] Doydee, P., 2005. Coastal Land use Change Detection Using Remote Sensing Technique: (Case Study in Banten Bay, West Java Island, Indonesia). Kasetsart Journal : Natural Science, 39(1), 159-164.

[26] Dupin, L., 2011. Mapping the landform assemblages and archaeological record of the Lower Khuzestan plain (SW Iran) using remote-sensing and GIS techniques. The Geological Society of America. Spec. Pap. 476, 53-68.

[27] Elkafrawy, S. B., Basheer, M. A., Mohamed, H. M., and Naguib, D. M., 2020. Applications of remote sensing and GIS techniques to evaluate the effectiveness of coastal structures along Burullus headland-Eastern Nile Delta, Egypt. Egyptian Journal of Remote Sensing and Space Science, In Press. https://doi.org/10.1016/j.ejrs.2020.01.002

[28] Fatima, H., Arsalan, M. H., Khalid, A., Marjan, K., Kumar, M., 2015. M. Spatio-temporal analysis of shoreline changes along Makran Coast using remote sensing and geographical information system. In Proceedings of the Fourth International Conference on Space Science and Technology (ICASE), Islamabad, Pakistan, 2-4.

[29] Galloway, W.E., 1975. Process framework for describing the morphological and stratigraphic evolution of deltaic depositional systems: In M.L. Broussard (Ed.), Deltas, models for exploration, 2nd ed. Houston, Texas: Houston Geol. Soc., pp: 87-98.

[30] Goudie, A. S., 2004. Encyclopedia of Geomorphology. Routledge, Taylorand Francis, London and New York 1156 p. 
[31] Gosh, T., Bhandari, G., and Hazra, S., 2001. Assessment of landuse/ landcover dynamics and shoreline changes of Sagar Island through remote sensing. 22nd Asian Conference on Remote Sensing, November, 848-852.

[32] Guariglia, A., Buonamassa, A., Losurdo, A., Saladino, R., Trivigno, M. L., Zaccagnino, A. and Colangelo, A., 2006. A multisource approach for coastline mapping and identification of shoreline changes. Annals of geophysics 49, (1) 295-304. https://www.annalsofgeophysics.eu/index.php/annals/article/view/3155

[33] Gunawan, I., 1998. Typical Geographic Information System (GIS) Applications for Coastal Resources Management in Indonesia. Indonesian Journal of Coastal and Marine Resources Management, Vol. 1 No. 1 pp: 1-12 in [61]

[34] Hamid, R., 2014. The concentration of salt in Shatt Al-Arab. Journal of Basra researches for Human Sciences, Vol. 39 No.4, pp.229-252.

[35] Hashmi, S. G. M., and Ahmad, S. R., 2018. GIS-Based Analysis and Modeling of Coastline Erosion and Accretion along the Coast of Sindh Pakistan. Journal of Coastal Zone Management, 21(1), 1-7. https://doi.org/10.4172/2473-3350.1000455

[36] Hussain, N. A.; Karim; H. H.; Al-Saad, H. T.; Yousif, O.H.; and AlSaboonchi, A.A., 1990. Shatt AlArab fundamental scientific studies. Marine science center, Dar Al-Hekma Publishing House, Univ. of Basrah, Iraq. 391p. [In Arabic]

[37] Intergovernmental Panel on Climate Change (IPCC), 2007. Climate Change. World Meteorological Organization, Geneva.

[38] Issa, I. E., Al-Ansari, N. A., Sherwany, G., Knutsson, S., 2014. Expected future of water resources within Tigris-Euphrates Rivers basin, Iraq. Journal of Water Resource and Protection. 6, pp.421-432. https://www.scirp.org/journal/paperinformation.aspx?paperid=45022

[39] Khan, M. S., Das, J., and Kabir, M. H., 2019. Monitoring Coastline Changes in the Coastal Belt of Chittagong in Bangladesh Using GIS and Remote Sensing. Asian Journal of Geographical Research, 2(3), 1-13. https://doi.org/10.9734/ajgr/2019/v2i330087

[40] Lan, P. T., Son, T. S., Gunasekara, K., Nhan, N. T., and Hien, L. P., 2013. Application of Remote Sensing and GIS technology for monitoring coastal changes in estuary area of the Red river system, Vietnam. Journal of the Korean Society of Surveying Geodesy Photogrammetry and Cartography, 31(6 PART 2), 529-538. https://doi.org/10.7848/ksgpc.2013.31.6-2.529.

[41] Li, X., Damen, M. C. J., 2010. Coastline change detection with satellite remote sensing for environmental management of the Pearl River Estuary, China. Journal of Marine Systems, Vol., 82, pp: S54-S61. https://doi:10.1016/j.jmarsys.2010.02.005 
[42] Mahapatra, R. R. M. and Rajawat A. S., 2013. Shoreline change monitoring along the south Guajrat coast using remote sensing and GIS techniques. https://pdfs.semanticscholar.org/a80d/afdb00b29bc1c44f58f970baba243771e742.pdf

[43] Makota, V., Sallema, R. and Mahika, C., 2004. Monitoring shoreline change using remote sensing and GIS: A Case Study of Kunduchi Area, Tanzania. Western Indian Ocean Journal of Marine Science, Vol. 3 No. 1, pp: 1-10. https://www.oceandocs.org/handle/1834/1138

[44] Mohammed, L.A., 1982. A desk study of the Shatt Al-Arab estuary. Unpublished M.Sc., Thesis Univ., of Strathelyde, Glasgow, 180p.

[45] Mohammed, A.; Al-Badran, B. and Hussain, N., 1999. Bathymetrical surveys of Shatt Al-Arab channel (from Qurmat Ali to Arabian Gulf), Final report. [In Arabic]

[46] Moore, L. J., 2000. Shoreline mapping techniques. Journal of Coastal Research, Vol. 16 No. 1, pp:111-124. https://www.jstor.org/stable/4300016?seq=1

[47] Morton, R.A., 2002. Coastal geoindicators of environmental change in the humid tropics. Environmental Geology, 42, pp.711-724. https://link.springer.com/article/10.1007/s00254-002-0549-4

[48] Motevalli, S., Hosseinzadeh, M. M., Derafshi, K., Gharehchahi, S., and Alijani, M. A. (2012). Coastline change detection using remote sensing and GIS at Tonekabon coast area during 1984 and 2010, Mazandaran Province, Iran. Life Science Journal, 9(4), 4174-4181.

[49] Murray, N. J., Phinn, S. R., Clemens, R. S., Roelfsema, C. M., \& Fuller, R. A. 2012. Continental scale mapping of tidal flats across East Asia using the Landsat archive. Remote Sensing, 4 (11), 34173426. https://doi.org/10.3390/rs4113417

[50] Muttitanon, W.; Tripathi, N.K., 2005. Land use/land cover changes in the coastal zone of Ban Don Bay, Thailand using Landsat 5 TM data. Int. J. Remote Sens. 26, 2311-2323.

[51] Natesan, U., Parthasarathy, A., Vishnunath, R., Kumar, G. E. J., and Ferrer, V. A., 2015. Monitoring Longterm Shoreline Changes along Tamil Nadu, India Using Geospatial Techniques. Aquatic Procedia. https://doi.org/10.1016/j.aqpro.2015.02.044

[52] Oyedotun, T. D. T. 2014. Shoreline geometry: DSAS as a tool for historical trend analysis. Geomorphological Techniques, 2, pp.1-12.

[53] Rasuly, A., Naghdifar, R., and Rasoli, M., 2010. Monitoring of Caspian Sea coastline changes using object-oriented techniques. Procedia Environmental Sciences, 2, 416-426. https://doi.org/10.1016/j.proenv.2010.10.046.

[54] Rio, L. D., Gracia, J. F. and Benavente, J., 2013. Shoreline change patterns in sandy coasts. A case study in SW Spain, Geomorphology, Vol. 196, 252-266pp. 
[55] Sefrioui, S., 2017. Adapting to Sea Level Rise: A Law of the Sea Perspective. In: Andreonne G (Ed) The future of the law of the sea: bridging gaps between national, individual and common interests. Springer, pp.3-22. https://link.springer.com/chapter/10.1007/978-3-319-51274-7_1

[56] Shalaby, A. and Tateishi, R., 2007. Remote sensing and GIS for mapping and monitoring land cover and land-use changes in the northwestern coastal zone of Egypt. Applied Geography Vol., 27, No.1, pp: 28-41. https://www.sciencedirect.com/science/article/abs/pii/S0143622806000154

[57] Thi, V. T., Xuan, A. T. T., Nguyen, H. P., Dahdouh-Guebas, F., and Koedam, N., 2014. Application of remote sensing and GIS for detection of long-term mangrove shoreline changes in Mui Ca Mau, $\begin{array}{llll}\text { Vietnam. } & \text { Biogeosciences, } & \text { Vol., } & \text { 11, 3781-3795. }\end{array}$ https://www2.ulb.ac.be/sciences/biocomplexity/pub/TranThietal_2014_Biogeosciences.pdf

[58] Totlal Tide Software: https://admiralty-totaltide.software.informer.com/1.0/

[59] United National Convention on the Law of the Sea (UNCLOS), 1982. Territorial sea and contiguous zone, PART II, Section 2. Limits of the territorial sea, Art.3, Breadth of the territorial sea. https://www.un.org/depts/los/convention agreements/texts/unclos/part2.htm

[60] U.S. Geological Survey, 2018. Earth Explorer, accessed on 16 June 2018. https://earthexplorer.usgs.gov/

[61] Winarso, G; Judijanto and Budhiman, S., 2001. The potential application remote sensing data for coastal study. 22nd Asian Conference on Remote Sensing. Singapore. 5-9pp. https://crisp.nus.edu.sg/ acrs2001/pdf/084Winar.pdf

[62] White, K. and El Asmar, H. M., 1999. Monitoring changing position of coastlines using Thematic Mapper imagery, an example from the Nile Delta. Geomorphology, 29(1-2), 93-105. https://www.sciencedirect.com/science/article/abs/pii/S0169555X99000082?via\%3Dihub

[63] Xu, N. (2018). Detecting coastline change with all available Landsat data over 1986-2015: A case study for the state of Texas, USA. Atmosphere. https://doi.org/10.3390/atmos9030107

[64] Yu, K., Hu, C., Muller-Karger, F. E., Lu, D., and Soto, I.. 2011. Shoreline changes in west-central Florida between 1987 and 2008 from Landsat observations. International Journal of Remote Sensing, $32(23)$, 8299-8313. https://doi.org/10.1080/01431161.2010.535045. 

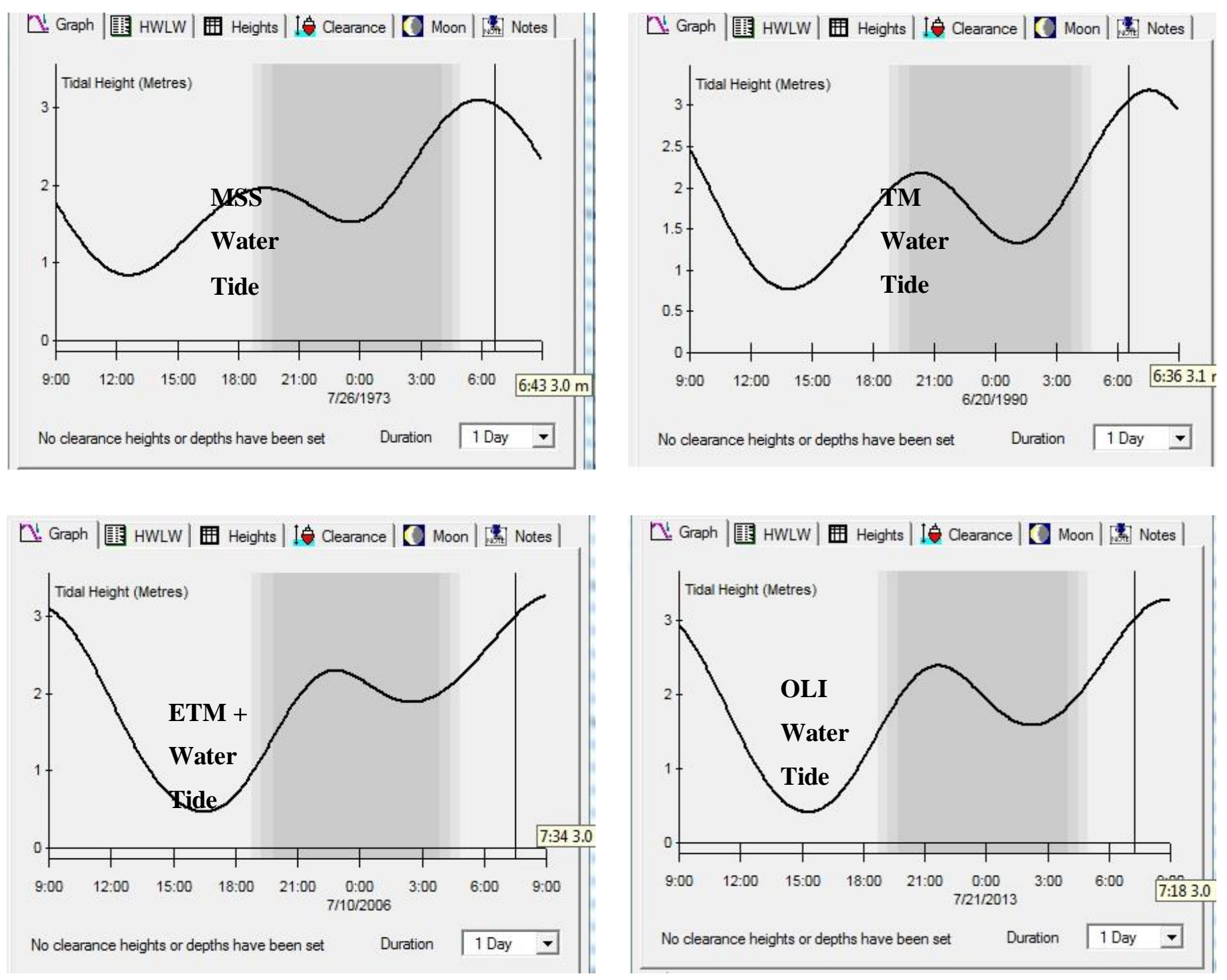

Figure 2. Total Tide software Water Tide Level for Landsat Images used in study (MSS, TM, ETM+, OLI) 

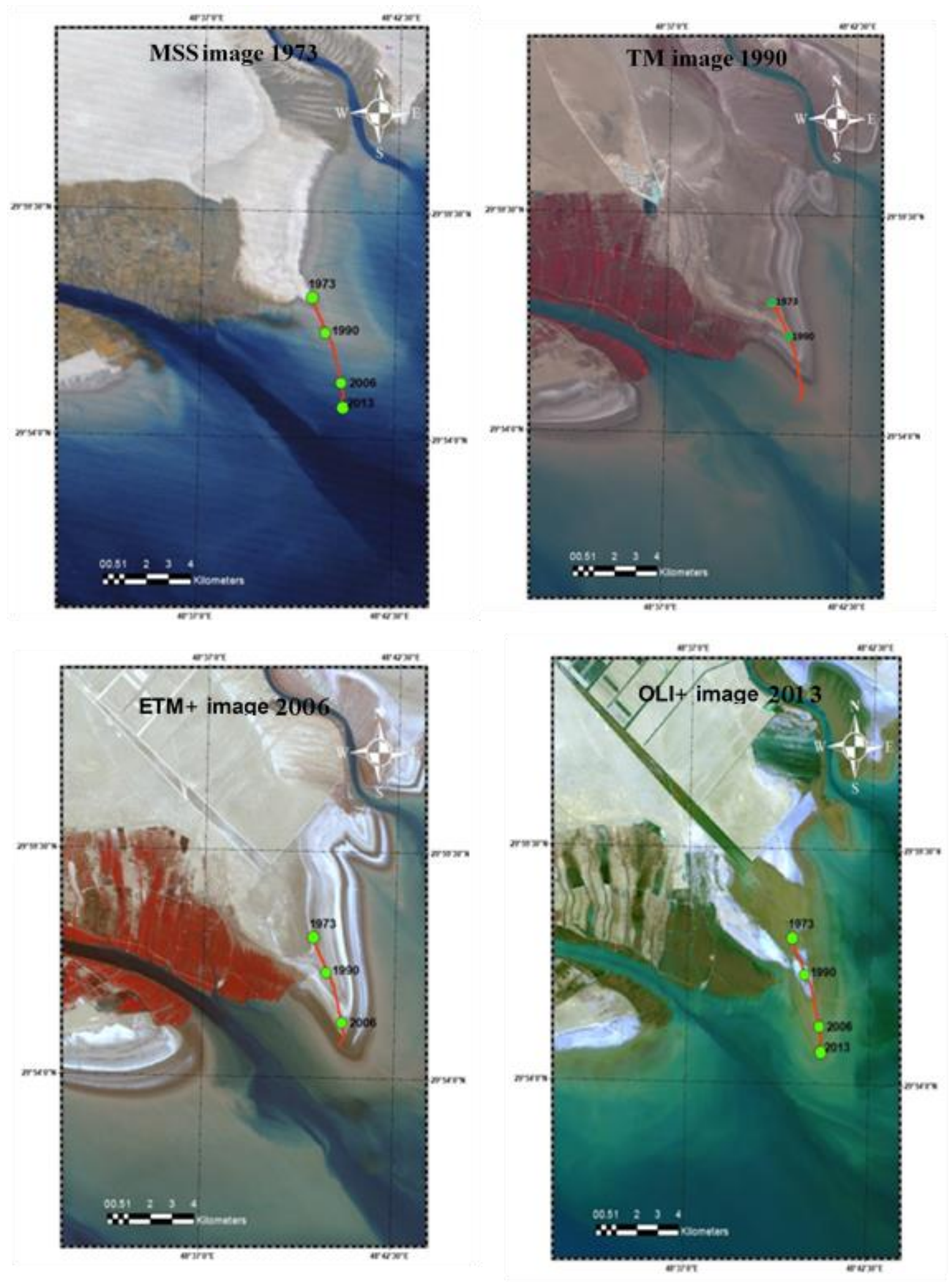

Figure 3. Shoreline direction and change detectionSatellite Image 

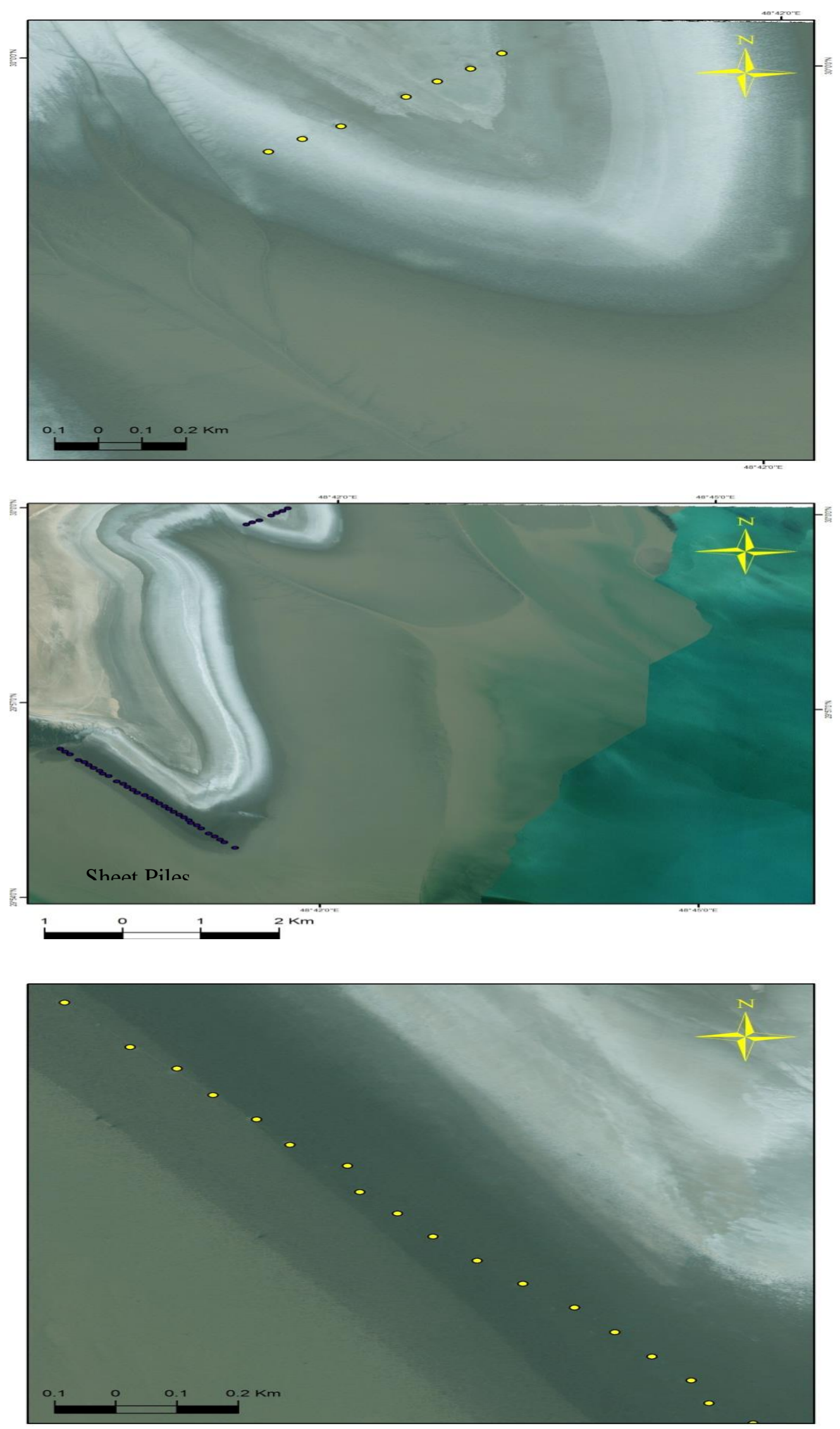

Figure 4. Sheet pile or groins for stabilization the shoreline of Maraqat Abadan. Quick-Bird Satellite Image $0.6 \mathrm{~m}$ 


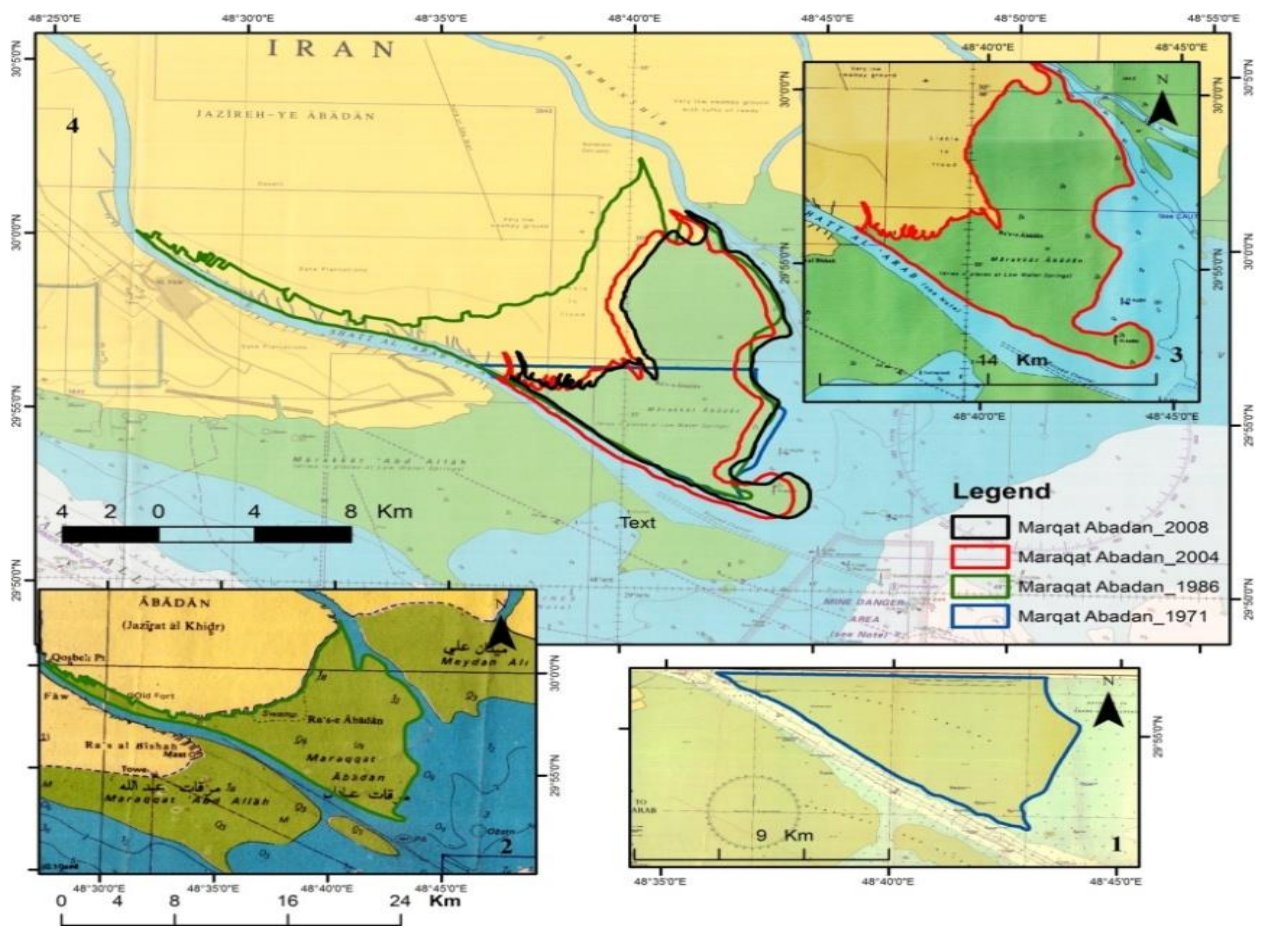

Figure 5. Baseline lines (zero line) and areas of the Abadan larvae from Admiral Maps by year, 1 (1971), 2 (1986), 3 (2004), 4 (2008) 